\title{
Transaction Costs and Suitability of Trading Currency - Case on Selected East Asian Economies
}

\author{
Gladys Siow
}

\begin{abstract}
Until recently, there are literatures that studied exporters in different countries are assumed to have increased their interest in setting prices in their own currency. However, they are concern about the business practice of "pricing to market" at the same time. In this paper, few Asian countries have been selected to compare costs trading in US dollar and Home Currencies (HC) unit. The countries include Japan, Malaysia, India, Singapore and Thailand as exporting countries. China's recent rapid growth made it a desirable trading destination, thus, it is chosen as partner country in this analysis. More developed countries like Japan and Singapore might also choose either to trade in USD or own local currencies as the differences are not so obvious compared to India. On the other hand, Malaysia and Thailand could consider trading using home currencies as it might bring more benefit than trading in USD. This study does not mean to ignore the effects of fluctuations of exchange rates. This study uses simple ratio and index to help in demonstrating the suitability of trading currency for a country. The findings can be used as a guideline for policy makers in proposing to trade using home currencies or foreign currency in order to create a win-win trading environment.
\end{abstract}

Index Terms - Currency cost, trading costs and benefits, competitive currency vs cooperative currency

\section{INTRODUCTION}

In more recent literature, exporters in different countries are assumed to have increased their interest in setting prices in their own currency. However, they are concern about the business practice of "pricing to market" at the same time. In general terms, "pricing to market" refers that exporters could price to market regardless of whether they invoice in their own currency ("producer currency pricing") or in the currency of the local market where the end products are sold ("local currency pricing") [1].

Until today, dollar still remains as the major internationally-used currency even since the Second World War living the euro, Japanese yen, pound sterling, and Swiss franc far behind in a number of dimensions. The US dollar is commonly used in foreign exchange market transactions, and for invoicing a range of commodities especially oil. However, lately in October 2000, the Iraqi government demanded the settlement of its petroleum exports in euro under the UN Oil-for-Food [2], while in April 2008, Iran stopped conducting oil transactions in US dollar [3]. There is also a case of crude oil exports to the United States being priced in Canadian dollars but settled in US dollars, so that

Manuscript received January 20, 2013; revised February 19, 2013.

Gladys Siow is with the University of Malaya, 50603 Kuala Lumpur, Malaysia. (e-mail: zysiow1101@gmail.com). the producers bear the exchange rate risk. Finally, Chinese oil companies such as CNOOC Ltd. and Petrochina Company Ltd. price their locally produced crude oil in US dollars on the basis of international benchmark grades but settle domestic contracts (the majority of their crude oil sales) entirely in renminbi [4].

\section{LITERATURE REVIEW}

Most of the theoretical literature on trade invoicing discusses money as a medium of exchange and demonstrates the role of vehicle currencies in the trading of goods or the exchange of currencies. If residents of a country may only hold non-interest bearing foreign currency assets, and their revenues or expenditures are at least partly denominated in a foreign currency, it is, transaction costs (i.e. brokers' fees, bookkeeping, and psychological inconvenience) make it profitable for them to hold foreign currency cash balances [5]. Other research mentions that "thick market" externality (e.g. economies of scale in foreign exchange markets) and trade parameters (i.e. degree of openness, the level of integration between the countries or transportation technologies) have an impact on the choice of vehicle currency.

Furthermore, industry characteristics are proved to have important role where homogeneous goods and traded is specialized markets likely to be invoiced in a single low transaction cost currency [6]. The fragmentation theory claims that fragmentation of production processes takes place when (i) production cost per se in fragmented production blocks can be substantially reduced and (ii) service link cost for connecting remotely located production blocks is not prohibitively high. If the reduction in production cost by fragmentation overweighs the service link cost incurred thereby, the firm breaks apart some of its production blocks to other remote locations, so as to attain a total cost reduction [7].

The first empirical study on currency invoicing was regarding Swedish exports mostly invoiced in Swedish krones and Swedish imports are mostly invoiced in the exporter's currency, at the meanwhile US dollar was not often used as invoicing currency [8]. Those findings were generalized and called Grassman's law in which producer currency pricing (PCP) is dominant for manufacturing trade between industrialized countries. US dollar is used in primary goods' trade while industrialized country's currency is used to invoice in trade between developing and industrialized countries. The Grassman's law describes that a firm with more market and bargaining power would choose its own currency to avoid exchange rate risk. 
There are a large number of theoretical and empirical studies that analyze the relationship between exchange rate volatility and international trade, eg. [9], [10]. Further studies on Asian currency union and optimal currency areas are summarized in Figure 1. There are other papers with different approaches like error-correction model and panel data techniques; different sample period and countries which found a negative relationship between exports and exchange rate volatility in East Asia [11]-[14]. Exchange rate volatility is proved to reduce electronic parts and components exports within East Asia region

Exchanges rates are one of the major factors that generate uncertainty in the competitiveness of business partners as well as service link costs. A production plants located in countries with high volatility in exchange rates are less likely to be incorporated into production networks. There are reports from Japanese companies claiming that exchange rate stability is important for back-and-forth transactions of intermediate goods in international production networks [15]

The act of choosing competitor's currency is known as "herding effect" [16]. This effect happens for industries with homogeneous goods where producers want to keep their prices stable relative to the competitors. There are also some other empirical studies on the invoicing choice. It includes cross-country invoicing choice analysis [1], [17]; invoicing currency choice in Canadian using imports data at a customs level spanning from February 2002 to February 2009 [18] and empirical tests of determinants of currency invoicing using questionnaire survey analysis with Swedish exporting firm [19]. Other studies include analysis on Canadian import invoicing [20], Japanese Yen more often used in industries with differentiated products like the automobile industry [21] and research on invoicing practice in Swedish exports and Dutch Trade respectively [22].

Another recent research by [23] using interview analysis with 23 Japanese representative firms in the automobile, electrical machinery, general machinery and electrical component industries to obtain information on their currency invoicing practices and their exchange rate risk management. They found that: (1) importer's currency invoicing is more common in Japanese exports to developed countries. It is because most of their exports are destined for local subsidiaries. If sales and/or production subsidiaries is having strong competition in the local markets, Japanese parent firms would have a stronger tendency to take an exchange rate risk in intra-firm trade by invoicing in the local (importer's) currency, which known as pricing-tomarket (PTM) behavior; (2) Japanese firms that export highly differentiated products or have a dominant share in global markets tend to invoice in Yen even in exports to developed countries; and (3) even Japanese firms' production based in Asian countries, exports from these production subsidiaries tend to be invoiced in US dollars as long as the final destination market is the United States. Both Japanese and Asian firms have to take exchange rate risks against the US dollar as long as the share of dollar invoicing is prevalent in Asia.

\section{RESEARCH Methodology AND ANALYSIS}

In this paper, few Asian countries have been selected to compare costs trading in US dollar and Home Currencies (HC) unit as shown in Table 1.0. The countries include Japan, Malaysia, India, Singapore and Thailand as exporting countries. China's recent rapid growth made it a desirable trading destination, thus, it is chosen as partner country in this analysis. Exports and imports value in USD are available at UN COMTRADE website while value in each countries' home currencies are obtained from countries' statistical yearbook. Since data in year 2010 is not available for some countries, thus data covers only from 2006 to 2009 to demonstrate the most recent trends of trading using different currencies. Most similar studies used more complex way especially one-way random-effects GLS panel and gravity model to analyze the currency invoicing and transaction costs. In this study, ratio of trading (exports/imports) has been compared in both USD and home currencies which are known as foreign ratio and domestic ration respectively. Ratio in year 2006 is set as basic year to calculate the costs. Finally, mean of ratio from year 2006 to 2009 are calculated in final column of table 1.0. Higher index indicates higher benefit to trade using that particular currency. The finalized data demonstrate that Japan, India and Singapore should probably remain to trade in USD as it rates higher benefit than local currencies. Though, from the analyzed data, more developed countries like Japan and Singapore might also choose either to trade in USD or own local currencies as the differences are not so obvious compared to India. On the other hand, Malaysia and Thailand could consider trading using home currencies as it might bring more benefit than trading in USD. However, this analysis could not conclude that it is a must to trade using currencies that could bring more benefit. Countries should always consider using currencies that create lowest costs especially in exchange rates fluctuation.

\section{CONCLUSION}

In this paper, few Asian countries have been selected to compare trading costs in US dollar and home currencies unit. From the analyzed data, more developed countries like Japan and Singapore might also choose either to trade in USD or own local currencies as the differences are not so obvious compared to India. On the other hand, Malaysia and Thailand could consider trading using home currencies as it might bring a slight more benefit than trading in USD. Some previous literatures also mentioned that Asian countries would tend to trade in USD as long as the final destination of their exports goes to the US market. This study uses simple method to demonstrate which currency is more suitable for partners' trading countries. It might be used as a reference for policy makers in proposing to trade using home currencies in order to create win-win trading environment for both countries. 


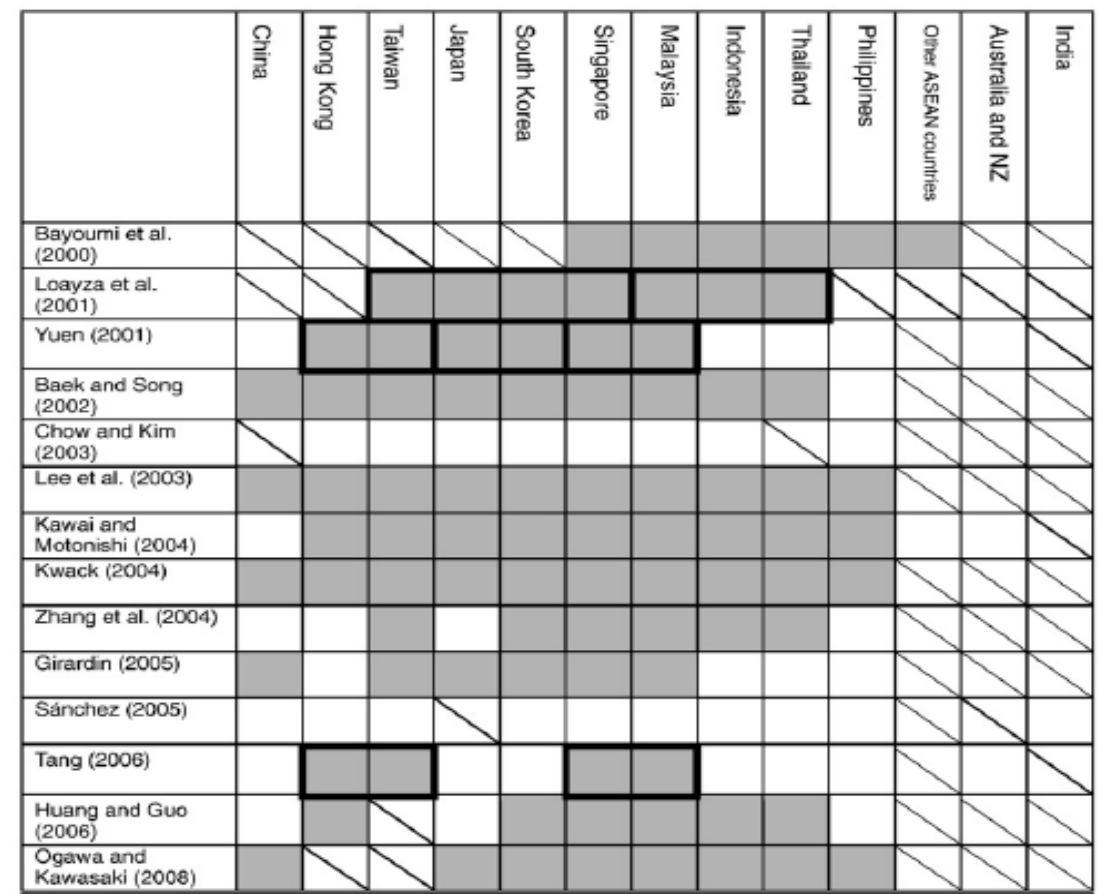

Fig. 1. Identified optimal currency areas. Shaded boxes indicate that countries are included in optimal currency areas identified in each paper. If severa optimal currency areas are identified in a paper, the boxes corresponding to each area are surrounded by thick lines. The boxes marked with diagonal lines indicate that those countries are not covered by the respective studies.

Source: [24]

TABLE I: COMPARISON OF TRADING INDEX (USD vS. HOME CURRENCIES)

\begin{tabular}{|c|c|c|c|c|c|c|c|c|c|c|c|}
\hline \multirow{2}{*}{ Year } & \multirow{2}{*}{ Reporters } & \multirow{2}{*}{ Partner } & \multirow{2}{*}{ Commodity } & \multirow{2}{*}{$\begin{array}{c}\text { Exports Value } \\
\text { to China (USD) }\end{array}$} & \multirow{2}{*}{$\begin{array}{l}\text { Exports } \\
\text { Value to } \\
\text { China (HC } \\
\text { in million) }\end{array}$} & \multirow{2}{*}{$\begin{array}{l}\text { Imports Value } \\
\text { from China } \\
\text { (USD) }\end{array}$} & \multirow{2}{*}{$\begin{array}{l}\text { Imports } \\
\text { Value from } \\
\text { China (HC } \\
\text { in million) }\end{array}$} & \multirow{2}{*}{$\begin{array}{l}\text { Foreign } \\
\text { Ratio } \\
\text { (EX/IM) - } \\
\text { in USD }\end{array}$} & \multirow{2}{*}{$\begin{array}{l}\text { Domestic } \\
\text { Ratio } \\
\text { (EX/IM) - } \\
\text { in HC }\end{array}$} & \multicolumn{2}{|c|}{$\begin{array}{l}\text { RATIO (with value in } \\
\text { year } 2006 \text { as base) }\end{array}$} \\
\hline & & & & & & & & & & $\begin{array}{l}\text { Foreign } \\
\text { Ratio } \\
\end{array}$ & $\begin{array}{l}\text { Domestic } \\
\text { Ratio } \\
\end{array}$ \\
\hline 2006 & Japan & \multirow{5}{*}{ China } & \multirow{5}{*}{$\begin{array}{l}\text { TOTAL } \\
\text { (HS1996) }\end{array}$} & $92,769,551,020$ & $¥ ¥ 10,794,000$ & $118,525,736,273$ & $¥ 13,784,000$ & 0.7827 & 0.7831 & 1 & 1 \\
\hline 2006 & Malaysia & & & $11,638,253,320$ & RM42,620 & $15,883,589,077$ & RM58,260 & 0.7327 & 0.7316 & 1 & 1 \\
\hline 2006 & India & & & $7,829,167,581$ & $\square 299,249$ & $15,639,063,508$ & 481,167 & 0.5006 & 0.6219 & 1 & 1 \\
\hline 2006 & Singapore & & & $26,491,279,266$ & $\$ 42,061$ & 27.211 .159 .599 & $\$ 43,194$ & 0.9735 & 0.9738 & 1 & 1 \\
\hline 2006 & Thailand & & & $11,774,180,471$ & B445,978 & $13,617,176,189$ & B521,524 & 0.8647 & 0.8551 & 1 & 1 \\
\hline 2007 & Japan & \multirow{5}{*}{ China } & \multirow{5}{*}{$\begin{array}{l}\text { TOTAL } \\
\text { (HS1996) }\end{array}$} & $109,270,655,883$ & $¥ 12,839,000$ & $127,922,365,758$ & $¥ 15,035,000$ & 0.8542 & 0.8539 & 1.091351 & 1.090487 \\
\hline 2007 & Malaysia & & & $15,443,850,730$ & RM53,037 & $18,841,697,859$ & RM64,713 & 0.8197 & 0.8196 & 1.118656 & 1.120324 \\
\hline 2007 & India & & & $9,491,978,178$ & $\square 375,148$ & $24,575,771,746$ & 787,295 & 0.3862 & 0.4765 & 0.771516 & 0.766175 \\
\hline 2007 & Singapore & & & $28,924,628,974$ & $\$ 43,549$ & $31,908,128,120$ & $\$ 48,013$ & 0.9065 & 0.9070 & 0.931131 & 0.931456 \\
\hline 2007 & Thailand & & & $14,872,545,725$ & B511,109 & $16,979,861,795$ & B564,566 & 0.8759 & 0.9053 & 1.012996 & 1.058668 \\
\hline 2008 & Japan & \multirow{5}{*}{ China } & \multirow{5}{*}{$\begin{array}{l}\text { TOTAL } \\
\text { (HS1996) }\end{array}$} & $124,900,515,034$ & $¥ 12,950,000$ & $143,229,984,360$ & $¥ 14,830,000$ & 0.8720 & 0.8732 & 1.114134 & 1.11512 \\
\hline 2008 & Malaysia & & & $19,012,611,886$ & RM63,435 & $20,046,601,790$ & RM66,854 & 0.9484 & 0.9489 & 1.29438 & 1.297052 \\
\hline 2008 & India & & & $10,093,926,793$ & $\begin{array}{l}\square 435,974 \\
\end{array}$ & $31,586,024,206$ & 1091161 & 0.3196 & 0.3996 & 0.638352 & 0.642443 \\
\hline 2008 & Singapore & & & $31,080,835,725$ & $\$ 43,817$ & $33,754,833,144$ & $\$ 47,595$ & 0.9208 & 0.9206 & 0.945803 & 0.945435 \\
\hline 2008 & Thailand & & & $15,997,870,399$ & B532,319 & $20,045,768,978$ & B670,343 & 0.7981 & 0.7941 & 0.922988 & 0.928615 \\
\hline 2009 & Japan & \multirow{5}{*}{ China } & \multirow{5}{*}{$\begin{array}{l}\text { TOTAL } \\
\text { (HS1996) }\end{array}$} & $109,727,427,882$ & $¥ 10,236,000$ & $122,574,080,731$ & $¥ 11,436,000$ & 0.8952 & 0.8951 & 1.143731 & 1.143007 \\
\hline 2009 & Malaysia & & & $19,103,882,149$ & RM67,358 & $17,245,921,353$ & RM61,026 & 1.1077 & 1.1038 & 1.511806 & 1.508796 \\
\hline 2009 & India & & & $10,370,052,494$ & $\square 426,613$ & $30,613,370,690$ & $1,476,056$ & 0.3387 & 0.2890 & 0.676651 & 0.464723 \\
\hline 2009 & Singapore & & & $26,302,522,753$ & $\$ 38,125$ & $25,927,368,791$ & $\$ 37,585$ & 1.0145 & 1.0144 & 1.042037 & 1.04169 \\
\hline 2009 & Thailand & & & $16,123,831,401$ & B548,760 & $17,028,921,054$ & B586,143 & 0.9468 & 0.9362 & 1.095059 & 1.094812 \\
\hline & & & & & & & & \multirow{5}{*}{$\begin{array}{l}\text { AVERAGE } \\
\text { (MEAN) }\end{array}$} & Japan & 1.08730 & 1.08715 \\
\hline & & & & & & & & & Malaysia & 1.23121 & 1.23154 \\
\hline & & & & & & & & & India & 0.77163 & 0.71834 \\
\hline & & & & & & & & & Singapore & 0.97974 & 0.97965 \\
\hline & & & & & & & & & Thailand & 1.00776 & 1.02052 \\
\hline
\end{tabular}

Source: Author's Compilation (value in USD available at UN COMTRADE; value in home currencies available at countries' statistical yearbook Notes: $\mathrm{HC}=$ Home Currencies

\section{REFERENCES}

[1] A. Kamps, The Euro as Invoicing Currency in International Trade, ECB Working Paper, 665, 2006.
[2] CNN. UN to Let Iraq Sell Oil for Euros, Not Dollars. (2000). [Online]. Available:

http://archives.cnn.com/2000/WORLD/meast/10/30/iraq.un.euro.reut/

[3] CBS. Iran Ends Oil Transactions in US Dollars. (2008). [Online] Available: 
http://www.cbsnews.com/stories/2008/04/30/business/main4057490.s html

[4] E. Mileva and N. Siegfried, "Oil market structure, network effects and the choice of currency for oil invoicing," Energy Policy, vol. 44, 2012, pp. 385-394.

[5] A. Swoboda, "The euro-dollar market: an interpretation," International Finance, vol. 64, 1968.

[6] R. McKinnon, Money in International Exchange: The Convertible Currency System, Oxford University Press, 1979.

[7] R. W. Jones and H. Kierzkowski, "The role of services in production and international trade: a theoretical framework," in: R.W. Jones, A.O. Krueger (Eds.), The Political Economy of International Trade: Essays in Honor of R.E. Baldwin, Basil Blackwell, Oxford, 1990.

[8] S. Grassman, "Currency Distribution and Forward Cover in Foreign Trade," Journal of International Economics, vol. 6, 1973, pp. 215221.

[9] P. Clark, N. Tamirisa, S. Wei, A. Sadikov, and L. Zeng, “A new look at exchange rate volatility and trade flows," International Monetary Fund, no. 235, 2004.

[10] M. McKenzie, "The impact of exchange rate volatility on international trade flows," Journal of Economic Surveys, vol. 13, no. 1, pp. 71-106, 1999.

[11] A. Bénassy-Quéré and A. Lahrèche-Révil, "Trade linkages and exchange rates in Asia: the role of China," Working paper, no. 21, CEPII, 2003.

[12] M. Chit, M. Rizov, and D. Willenbockel, "Exchange rate volatility and exports: new empirical evidence from the emerging East Asian Economies," Middlesex University Economics and Statistics Discussion Paper, no. 127, 2008.

[13] W. Poon, C. Choong, and M. Habibullah, "Exchange rate volatility and export for selected East Asian countries: evidence from errorcorrection model," ASEAN Economic Bulletin, vol. 22, no. 2, pp. 144 $159,2005$.

[14] W. Thorbecke, "The effect of exchange rate volatility on fragmentation in East Asia: evidence from the electronics industry," Journal of the Japanese and International Economies, vol. 22, no. 4, pp. 535-544, 2008 .

[15] T. Ito, S. Koibuchi, Y. Sasaki, K. Sato, J. Shimizu, K. Hayakawa, and T. Yoshimi, "Choice of invoice currency and exchange risk management: Case studies of Japanese firms," RIETI Discussion Paper Series 08-J-009 (in Japanese), 2008.

[16] S. L. Goldberg and C. Tille, "Vehicle Currency Use in International Trade," NBER Working Paper, no. 11127, 2005.

[17] S. L. Goldberg and C. Tille, "Vehicle Currency Use in International Trade," Journal of International Economics, vol. 76, no. 2, pp. 177 192, 2008.

[18] S. L. Goldberg and C. Tille, "Micro, Macro, and Strategic Forces in International Trade Invoicing," NBER Working Paper, no. 15470 , 2009.

[19] F. Richard and F. Wilander, "The Currency Denomination of Exports--AQuestionnaire Study," Journal of International Economics, vol. 75, pp. 54-69, 2008.

[20] D. Shabtai and A. Haug, "Currency Invoicing in International Trade: An Empirical Investigation," Review of International Economics, vol. 11, no. 2, pp. 332-345, 2003.

[21] O. Hiroyuki, A. Otani, and T. Shirota, Monetary and Economic Studies, vol. 22, no. 1, pp. 27-63, 2004.

[22] J. Silva, "Determinants of the Choice of Invoicing Currency: From Dutch Guilders to Euros in Dutch Goods Trade," Tilburg University mimeo, 2004.

[23] I. Takatoshi, K. Satoshi, S. Kiyotaka, and S. Junko, "Determinants of Currency Invoicing in Japanese Exports: A firm-level analysis," RIETI Discussion Paper Series, no. 10-E-034, 2010.

[24] S. Watanabe and M. Ogura, "How far apart are the two ACUs from each other? Asian currency unit and Asian currency union," Emerging Markets Review, no. 11, pp. 152-172, 2010.

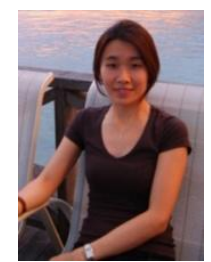

Gladys Siow was born in Johor, Malaysia in 1988. In 2009, Bachelor's degree on international business was earned in Troy University, Alabama, USA. She is currently a Ph.D. student in University of Malaya, Kuala Lumpur, Malaysia. 